\title{
The Role of Lawyers in Producing the Rule of Law: Some Critical Reflections*
}

\author{
Robert W. Gordon ${ }^{* *}$
}

\section{INTRODUCTION}

For the last fifteen years, American and European governments, lending institutions led by the World Bank, and NGOs like the American Bar Association have been funding projects to promote the "Rule of Law" in developing countries, former Communist and military dictatorships, and China.

The Rule of Law is of course a very capacious concept, which means many different things to its different promoters. Anyone who sets out to investigate its content will soon find himself in a snowstorm of competing definitions. Its barebones content ("formal legality") is that of a regime of rules, announced in advance, which are predictably and effectively applied to all they address, including the rulers who promulgate them - formal rules that tell people how the state will deploy coercive force and enable them to plan their affairs accordingly. The slightly-more-than barebones version adds: "applied equally to everyone."1

This minimalist version of the Rule of Law, which we might call pure positivist legalism, is not, however, what the governments, multilateral

* This Article is based on the second Annual Cegla Lecture on Legal Theory, delivered at Tel Aviv University Faculty of Law on April 23, 2009.

** Chancellor Kent Professor of Law and Legal History, Yale University. I am indebted to the University of Tel Aviv faculty for their generous hospitality and helpful comments, and especially to Assaf Likhovski, Roy Kreitner, Ron Harris, Hanoch Dagan, Daphna Hacker, David Schorr, Daphne Barak-Erez and Michael Zakim.

1 See generally Brian Tamanaha, On the Rule of Law: History, Politics, TheORY 26-91 (2004) (providing a lucid inventory of the various common meanings of the phrase). 
positivist legalism, is not, however, what the governments, multilateral lenders and NGOs have been promoting. All of the active projects have some specific substantive and institutional content.

Multilateral lending institutions (development banks) have tended to favor the general position - loosely traceable to Max Weber and Douglass North in one version, and to Milton Friedman and Friedrich Hayek in another that well-functioning markets require the support of a framework of clearly defined and effectively and predictably enforced legal rules and rights. At the height of the so-called Washington Consensus in the 1990 s, neo-liberal promoters stressed in particular that the Rule of Law protects property rights, especially in foreign direct investment, and enforces contracts (sometimes adding that it also entails low marginal tax rates and levels of regulation).

The human rights NGOs' version is the more classical or traditional view that the Rule of Law requires legal constraints on a state's authority to search, arrest, imprison, torture or kill persons in its jurisdiction. (Surprisingly little attention was given in these projects to the Rule of Law as law and order, law as the solution to Hobbesian anarchy; probably since in the minds of many of these project developers the basic problems needing solution were corrupt and overreaching and oppressive states and their bureaucracies, not weak or failed states. ${ }^{2}$ ) Much broader notions of the Rule of Law, however, have contemplated an extensive array of state functions to supply public goods such as healthcare and education infrastructure, to constitute the conditions facilitating trade and commerce, and to regulate harmful private as well as public conduct, such as mistreatment by husbands in patriarchal families. ${ }^{3}$ And others propose still more ambitiously that the Rule of Law implies "social and

2 In Paul Bremer's Iraq, to take an extreme example of misplaced priorities, the Coalition Provisional Authority felt it much more urgent to privatize industries, write a securities law, and substitute a flat for a progressive tax than to retain state police and military forces capable of containing looting and sectarian killing. See RAJIV CHANDRASEKARAN, IMPERIAL LIFE IN THE EMERALD CITY (2006).

3 For valiant and useful attempts to sort out the various applied versions of the Rule of Law see for example, TAmanAHA, supra note 1; Richard H. Fallon,The Rule of Law as a Concept in International Discourse, 97 CoLUM. L. REV. 1 (1997); Rachel Kleinfeld, Competing Definitions of the Rule of Law, in PROMOTING THE RULE of LaW ABRoad: IN SEARCH OF KNOWLEDGE 31 (Thomas Carothers ed., 2006); Alvaro Santos, The World Bank's Uses of the "Rule of Law" Promise in Economic Development, in THE New LaW and ECONOMIC DeVELoPMENT: A Critical APPRAISAL 253 (David M. Trubek \& Alvaro Santos eds., 2006); Thomas C. Heller, An Immodest Postscript, in BEYOND COMMON KNOWLEDGE: EMPIRICAL APPROACHES TO THE RULE OF LAW 382 (Erik G. Jensen \& Thomas C. Heller eds., 2003). William Whitford argues for a minimalist use of the term (establishment of institutions that make good on the political commitment of governments to act in 
economic rights" - that legal systems have positive obligations to develop state, group and individual capacities to act aggressively to restructure their societies, to eliminate obstacles to economic opportunity and mobility and to democratic participation, and to alleviate extremes of poverty, inequality and insecurity. In the last ten years the World Bank (which is really a congeries of divisions with competing ideas of how to promote development) has adopted a "comprehensive" approach to development, much influenced by the work of Amartya Sen, which incorporates all these versions of the Rule of Law simultaneously.

All of these visions have converged on an institutional program. The framework of market-supporting rules requires a set of institutions, staffed with people with appropriate training and motivation, to do the defining and enforcing. Human rights protection requires adequate processes and independent officials to enforce rule-of-law constraints against police, prosecutors, jailers and the military. Only the social and economic development programs purported to rely importantly on agencies outside the state. For most of the planners, the appropriate institutions were courts staffed with "independent" judges. The practical rule-of-law projects that have been most favored in developing and transitional societies have been those that focus on building judicial capacity - strengthening courts and improving the quality and training of judges - and establishing constitutional arrangements that define the scope of restraint over the exercise of governmental powers and protect individual rights. ${ }^{4}$

The reformers of an earlier - 1960s-70s - generation of "law and development" projects funded by USAID and the Ford Foundation believed that "formalist" judges and lawyers were obstacles to development and tried to produce a new elite of legal-realist Progressive-New-Deal model technocrats. They became disillusioned with their own project, as the lawyers they trained (mostly in Latin America) went to work for multinational corporations or military dictatorships. ${ }^{5}$ Some of the 1990s Rule-of-Law

accordance with pre-established rules and standards). See William C. Whitford, The Rule of Law, 2000 WIS. L. REv. 723.

$4 \quad$ The rule of law remains principally about improving the quantity (number and productivity) and quality (autonomy, pay scales, skills) of a largely existing court system under the partially articulated theory that well-functioning legal institutions are essential to markets and democracy, and that these, in turn, define the possibilities of successful development.

Heller, supra note 3, at 384 .

5 This was the conclusion of one of the best studies of the 1960s "Rule of Law" projects: JAMES GARDNER, LEGAL IMPERIALISM (1980). See David M. Trubek, The "Rule of Law" in Development Assistance: Past, Present and Future, in THE NEW 
promoters apparently knew about these earlier efforts, but never learned much from them, and in any case had other priorities. For the neo-liberals especially, the problem was bureaucracies - corrupt, clientelistic, swollen, expensive and inefficient. They distrusted "governments" but favored "governance," which meant shifting power out of bureaucracies and into cadres of newly trained and "independent" judges.

The general picture of the institutions that administer and maintain the Rule of Law in these projects is surprisingly under-specified. But plainly it is a transplant of a simplified and idealized model of Western, especially Anglo-American, judicial systems. Judges are chosen by such means and given such incentives (through training, promotion, tenure, pay) as to ensure their independence from the executive and from political or factional pressures and interests. Their allegiance is to "the law," also imagined as in Western formalist traditions as an autonomous body of rules and procedures.

But where is this body of law to come from: who are the lawgivers and how do they make the law? One of the oddest features of the Rule of Law manifestoes is that legislation is mostly missing from the picture. "Democracy" is often specified as a desired goal of development projects, but that seems to mean mostly elections, not representative bodies carrying on partisan political fights over the content of the laws. As critics of neo-liberal Rule of Law projects have pointed out, institutional economics suggested that legal rules supporting property and contracts were crucial; but public choice theory said states couldn't be counted on to produce such rules. ${ }^{6}$ Frequently of course, as a practical matter, the law in question is made by foreigners drafting constitutions and codes or regulatory laws that must be adopted wholesale as a condition for receiving multilateral assistance. But from whatever source the package of basic private-law rules might originate, Rule of Law promoters have tended to assume its content is autonomously given - perhaps by a Hayekian process whereby common-law judges incorporate rules generated in the spontaneous order of custom, or by a Weberian process whereby judges neutrally apply codes drafted by expert jurists and derived from general transhistorical principles, or else by a Chicago-style law-and-economics process whereby judges apply precedents embodying evolutionarily efficient legal rules. They have also assumed that once the package of rules was in place, judges, if properly trained, motivated and insulated from outside pressure,

LAW AND ECONOMIC DEVElopMENT: A CRITICAL APPRAISAL, supra note 3, at 74, for a concise sardonic account of the $1960 \mathrm{~s}$ projects and their successors.

6 See generally David Kennedy, The "Rule of Law," Political Choices, and Development Common Sense, in THE NEW LAW AND ECONOMIC DEvelopmENT: A CRITICAL APPRAISAL, supra note 3, at 95, 139-50. 
would apply the framework impartially, without fear or favor or improper political or factional influence - and that parties litigant and the state would accept and abide by their decisions.

So far, it must be admitted, most of the Rule of Law projects haven't worked out too well. The sponsors themselves have by now produced an admirably self-critical, tamed and chastened literature on failed experiments. The promoters can point to a handful of notable successes - projects in Eastern European countries with the closest ties to Western Europe such as Poland and Czechoslovakia; the establishment and staffing in several other countries of agencies with a largely technical mandate like antitrust or public utility or securities regulation; and the Chilean criminal law reforms. (Criminal justice and policing were naturally exempt from the general suspicion of government, and reforms in those areas targeted at improving efficiency and fairness and reducing corruption and arbitrary treatment.) Most reforms haven't taken or have had only modest results. A recent World Bank report said: "Most of these interventions produced little change. . . . As experience grew, it became clear that the roots of poor performance in the judicial system lay much less in a lack of resources and skills than in the behavior of judges, clerks, lawyers and litigants. "7 The very people relied upon to execute the project seem to have gotten in the way. ${ }^{8}$

My interest in these projects is in their assumptions, explicit or implicit, about how legal actors and institutions historically have contributed in Western societies, and thus by extension might contribute in developing or transitional societies, to constructing the complex of norms, institutions, specialized staffs, and cultural dispositions that make up the (incredibly plural and contested) set of social practices that are grouped under the broad umbrella label of the "Rule of Law." Some of these assumptions take the form of embedded historical narratives about the role of law in constructing markets and liberal institutions in the West - narratives often suggesting some ideal priorities (e.g. law promoting security and property rights needs to come first, democracy, human rights and social welfare later $\left.{ }^{9}\right)$. Some focus more particularly on the agency of legal actors, legal professions, lawyers and

7 THE INT'L BANK FOR RECONSTRUCTION \& DEV., WORLD BANK, ECONOMIC GROWTH IN THE 1990s: LEARNING FROM A DECADE OF REFORM (2005) (emphasis added).

8 These disappointments have not stopped or slowed the funding of many new projects. As observers have pointed out, the advantage of the "Rule of Law" rubric is that it promises something to many different constituencies, and that as its aims grow broader it becomes harder to assess their achievement or failure. See, e.g., Santos, supra note 3, at 278-95.

9 See the debate between Fareed Zakaria and Thomas Carothers: FAREED ZAKARIA, THE FUTURE OF FREEDOM: ILLIBERAL DEMOCRACY AT HOME AND ABROAD (2003) 
judges in promoting cultures of legalism, secularism, rationality and political liberalism.

Critics of the "Rule of Law" programs have called many of these assumptions into question. Some critics say that the models of development in the programs rely on narratives of "modernization" or underspecified "property rights" that are false depictions even of Western experience, where, for example, not strict protection but creative destruction of property rights paved the path to industrialization. ${ }^{10}$ Others point out that many societies, especially the tigers of North Asia, have undergone rapid economic growth despite the absence of effective legal institutions to protect property and enforce contracts; in these societies, as in earlier phases of Western capitalism, regimes of private enforcement, through merchant associations or religious or kinship groups, were adequate substitutes. ${ }^{11}$ In the same societies, moreover, economic development has been promoted by its supposed obstructers, highly activist and interventionist states. ${ }^{12}$ Still others suggest that law is largely superstructural or epiphenomenal, an effect rather than a cause; so that social change initiated by top-down changes in legal rules and institutions is bound to be ineffectual or resisted; and that bottom-up movements of empowered ordinary citizens are more important agents for constructing the political arrangements and cultural dispositions necessary for economic growth or the flourishing of human affairs. ${ }^{13}$ Where lawyers appear at all in such visions of

(arguing that developing or transitional societies do well to avoid rushing to adopt democratic politics; they should start with autocratic government, and gradually introduce market reforms and the rule of law); THOMAS CAROTHERS, Zakaria's Complaint, in CRITICAL Mission: EsSAYS ON DEMOCRACY PROMOTION 219 (2004) (arguing that Zakaria's model fits some historical and current societies but not many others where democratic demands have been preconditions for economic development and legal reform).

10 See, e.g., Frank Upham, Mythmaking in the Rule of Law Orthodoxy, in Promoting THE RULE OF LAW ABROAD: IN SEARCH OF KNOWLEDGE, supra note 3, at 75.

11 See the many contributions of Avner Greif, for example, Avner Greif, Commitment, Coercion and Markets: The Nature and Dynamics of Institutions Supporting Exchange, in HANDBOOK OF NEW INSTITUTIONAL ECONOMICS 727 (Claude Ménard \& Mary M. Shirley eds., 2005).

12 See, e.g., John Ohnesorge, Developing Development Theory: Law and Development Orthodoxies and the Northeast Asian Experience, 28 U. PA. J. INT'L ECON. L. 220 (2008).

13 See, e.g., Jane Stromseth, David Wippman \& Rosa Brooks, Can Might Make RIGHT? BUILDING THE RULE OF LAW AFTER MiLITARY INTERVENTIONS (2006); LAW AND GLOBALIZATION FROM BELOW: TOWARDS A COSMOPOLITAN LEGALITY (Boaventura de Sousa Santos \& César A. Rodríguez-Garavito eds., 2005). 
how to promote social change, it is as advisers to grass-roots social movements and community organizations.

The "Rule of Law" programs and their critiques all touch on the most basic, longstanding questions of legal sociology, legal history and classical social theory: the centrality of law to the rise of capitalism and political liberalism; the autonomy (or lack thereof) of legal norms, doctrines and institutions from political factions and material interests.

This set of concerns obviously opens up an unmanageably vast field of inquiry. My agenda here is just to try to clarify a little piece of it: the piece that deals with the implicit histories, in the "Rule of Law" programs and their intellectual underpinnings, of the roles played by legal professionals in constructing and applying the norms, institutions and "cultures" of capitalism, liberalism and democracy. I've been tempted many times to abandon even this little project, because legal professions differ so much from one another in different societies, and different periods, in their composition, tasks, economic and political situations and opportunities, degrees of self-organization, dependence on clienteles or state patronage, that maybe not much useful of a general nature can be said about them and their social roles. But I seem to be still here plugging away, on the assumption that despite all these differences, legal professions across common law and civil law jurisdictions, and more importantly across societies in the developed, ex-Communist, and developing world exhibit enough common characteristics - those of corps of persons accorded special authority or privileges to interpret the law on behalf of clients or the public; or to plead or sit in courts. Any particular comparison may, of course, always be challenged by having somebody point out that the "lawyers" in one society perform entirely different functions from those in another. ${ }^{14}$

Any idea of the Rule of Law has to presuppose the institutional arrangements and agents, and the political and social agreements supporting them, who will make it real and effective. Judges have to come equipped with the ideas of professional honor and the motivations and social power to enforce the rules - rather than, for example, to cater to the officials or family clans or local notables to whom they owe their positions; or to

14 For comparative projects that perceive the problem but go ahead on the basis of this assumption see for example, LAWYERS IN SOCIETY (Richard L. Abel \& Philip S.C. Lewis eds., 1988, 1989 \& 1995) (four volumes); FIGHTING FOR Political Freedom: COMPaRative STUdies of THE Legal COMPLEX AND POlitiCal Liberalism (Terence C. Halliday, Lucien Karpik \& Malcolm M. Feeley eds., 2007) (in which the "legal complex" includes judges, private lawyers, public lawyers like prosecutors and legal academics). 
the litigants from whom they receive their bribes. As I say, most of the Rule of Law projects focused chiefly on judges and courts, but eventually came to realize that law also needs lawyers: agents who communicate the rules through advice to private clients and governments and enable them to organize their businesses and structure their transactions and comply with regulations and tax laws and constitutional limitations; and who can negotiate and if necessary litigate with the state and other private parties when their claims of rights are impaired or disputed. Legal regulations and procedures are complicated and rapidly changing; so that sophisticated, experienced agents who know their way around the rule-systems and the courts are generally essential to effective representation within and operation of the system. ${ }^{15}$

But of course once you add in the lawyers, you have to face a whole new set of headaches. Lawyers, both individually and in the guilds they organize to regulate themselves and further their collective purposes, have their own agendas, ideologies and interests. Their dominant interests lie in establishing and protecting reliable sources of fees, social status and privileges; and in controlling markets for their services. ${ }^{16}$ Surely sometimes those interests would support aspects of the variously defined Rule of Law projects, but just as often subvert or impede it.

How can lawyers promote the Rule of Law?

To be fair, although it is lamentably true that many of the Rule of Law projects, especially in the early years of their formulation, adopted a model of law as self-enforcing rules, or - just about as naïve - a model of rules transmitted frictionlessly to addressees and enforced literally and impartially by judges, others were informed by more complex accounts, based loosely on the history of Western legal institutions, of how law and lawyers could produce the Rechtsstaat.

Here's a summary of some of the positive claims for lawyers as builders of the Rule of Law, that is, as agents for the promotion of three kinds of liberalization. First, lawyers are agents of legal liberalization; they build the specifically-legal institutions and culture of the Rule of Law - the Rechtsstaat constrained by requirements to act through the forms and procedures of legality, regularity and due process, the substitution of regular legal processes supervised by an independent judiciary for both official

15 See generally Gillian Hadfield, Don't Forget the Lawyers, 56 DePaUl L. ReV. 401 (2007).

16 Richard L. Abel's impressive body of work massively documents this view of the profession. See, e.g., RICHARD L. ABEL, AMERICAN LAWYERS (1989); RICHARD L. Abel, The Legal Profession IN ENGland AND WaLes (1988). 
and private violence, predation and corruption; and they help to diffuse the cultural norms of respect for and habitual resort to law and legal authorities, as also of rights-consciousness among the people.

Second, they are agents of political liberalization, by defending the basic frameworks of rights to speech, press, assembly, petition, free elections and political party organization, protection against arbitrary arrest and imprisonment; and the protection of minorities from persecution and discrimination.

And third, they are agents of economic liberalization - achieved by construction of (at a minimum) legal regimes sustaining the basic institutions of liberal capitalism: markets, property rights, contract enforcement, efficient forms of business organization. (Rather less often the manifestoes add: regulation underwriting capital markets, and supplying protection against fraud, extortion, and various kinds of nasty spillovers; and the capacity to extract taxes to pay for all these public goods.) The social role ascribed to lawyers in this process is either something like Max Weber's, that lawyers and their law are agents of rationalization, predictability, regularity, transparency; or simply that lawyers, as facilitators for business clients, help to produce the legal frameworks that such clients require.

How do these claims stand up to historical analysis? Most work on actual professions suggests a much less romantic and indeed distinctly mixed picture of the role of lawyers in building the clusters of norms and institutions that add up to the legal framework of liberal societies.

\section{ON LEgal LibERALIZATION}

The positive case for lawyers' historical contributions seems strongest with respect to legal liberalization, promotion of the rule-of-law ideals and framework and the cultures of legalism and legal rights-consciousness. Even in the many societies in which lawyers primarily work for an authoritarian state, at least they insist that the state be a Rechtsstaat, working through regular and orderly procedures to achieve its aims. Tocqueville famously compared lawyers in the United States to the European aristocracy, an elevated class with conservative habits and instincts, who serve as a check on both authoritarian and populist impulses. Lawyers, he argued, generally love order and stability (at least as long as they are included in the governing 
order - if excluded, they may lead revolutions). ${ }^{17}$ Anglo-American lawyers in particular are professionally conservative because attached to the past through common-law method, with its respect for precedent. Lawyers promote institutions and procedures that will use their skills, services and reasoning modes: judicial review of legislative and administrative action, trial-type procedures for determining facts, and the like. Such processes and constraints often serve as practical limits on state power, and a means to make such power accountable and transparent, or at least to put up roadblocks to its arbitrary exercise; and may even deliver weapons to the weak, who can exploit the resources of legality and turn them against stronger private parties and their rulers. This last was E.P. Thompson's well-known defense of the Rule of Law as an "unqualified human good": yes, law is generally the instrument of the powerful; but it also limits their power and delivers resources to their weaker adversaries. ${ }^{18}$ At a minimum, law substitutes for anarchy and violence: jaw-jaw is better than war-war.

If the legalist ideal, however, is law consistently and predictably applied, it's hardly obvious that the introduction of lawyers and the skills and procedures to which they are attached will serve that ideal. The biggest problem - the basis of charges leveled against lawyers since antiquity - is of course that lawyers profit from delay and complexity, which makes vindicating rights uncertain, costly and slow, and usually favors richer parties; and that legal talent tends to serve those who can pay its fees and protect its privileges, which generally also favors the rich and powerful. The openness of courts and litigation remedies to different classes of litigants is exceedingly various across time and societies; but everywhere many of law's procedures are restricted in practical use to the few who can afford them. The English Industrial Revolution produced massive externalities in the form of polluted air and water, life-shortening damage to humans and animals. Theoretically the victims had rights to sue in nuisance for injunctions or damages. Few such suits were ever brought except by large landowners; everyone else from the middle class downward was excluded from the system..$^{19}$ Meanwhile common lawyers strenuously opposed alternative administrative procedures that would have regulated at

17 AleXis de ToCQueville, Democracy IN AMERICA 263-65 (J.P. Mayer \& Max Lerner eds., George Lawrence trans., Harper and Row 1966) (1835).

18 E.P. THOMPSON, WHIGS AND HUNTERS: THE ORIGINS OF THE BLACK ACT 259 passim (Pantheon Books 1975).

19 See J.P.S. McLaren, Nuisance Law and the Industrial Revolution: Some Lessons from Social History, 3 OXFORD J. LEGAL STUD. 155 (1983). 
lower costs. ${ }^{20}$ In today's India, "delay is endemic"; cases sit on dockets for three to ten years or more; the bar resists all attempts at reform, and judges are too afraid of the bar to impose discipline; the lower courts serve some of the weak, "those who want to postpone paying taxes or debts or who want to forestall eviction," but mostly favor dominant parties, government bodies who use law's delays and expense to harass adversaries, and business defendants who refuse to settle claims against them. ${ }^{21}$

The rhetoric of legal professions celebrates the legalist ideal that the law be applied and available equally to all; but by and large these professions have rarely taken the initiative to secure practical access to justice, either through subsidizing legal services or permitting non-lawyer competitors (though they do tend to support legal-aid programs once established). Lawyers dependent on powerful clienteles are rarely friendly to the spread of general rights-consciousness that would permit legal remedies against those clienteles. Consider the attempts by elite U.S. bar associations to wipe out the plaintiffs' personal-injury bar through restrictive ethics rules prohibiting solicitation and contingency fees; business lawyers' current promotion of "tort reforms" that close off access to the tort system and jury trial for products liability plaintiffs; and "unauthorized practice" prosecutions that prevent lay competition even in markets lawyers don't serve. ${ }^{22}$ In Brazil, Joaquim Falcão tells us,

the great majority [of citizens] can neither hire a lawyer nor count on a state-supported legal aid lawyer to protect their rights . . . [They] are deprived of those benefits [of the rule of law] by reason of their poverty, the chronic inefficiency of the judiciary, and the culture of legal formalism, [which] has meant an uncritical attitude toward the political regime, the economic system, and the legal order itself. ${ }^{23}$

As we've seen, the primitive legalist version of the Rule of Law sees law as rules, uniformly applied to all they address. But the business of lawyers is to interpret the rules - which, however clear in formulation, always have gaps, ambiguities and conflicts — in ways that favor their

20 See generally HARRY ARTHURS, WITHOUT THE LAW: ADMINISTRATIVE JUSTICE AND Legal Pluralism IN Nineteenth Century EnGland (1985).

21 Marc Galanter \& Jaynath K. Krishnan, Debased Informalism: Lok Adalats and Legal Rights in Modern India, in BEYOND COMMON KNOWLEDGE: EMPIRICAL APPROACHES TO THE RULE OF LAW, supra note 3, at 96, 100-01.

22 See generally DEBORAH L. RHODE, ACCESS to JustiCe (2004).

23 Joaquim Falcão, Lawyers in Brazil, in LAWYERS IN SOCIETY, VOLUME 2: THE CIVIL LAW WORLD 400, 402 (Richard L. Abel \& Philip S. C. Lewis eds., 1988). 
clients. Theoretically that is not a problem if varying interpretations can be resolved authoritatively by judges, whose own varying interpretations may in turn be harmonized and made uniform through appeals and professional disciplinary controls. But the lawyers also control (especially in adversarial proceedings) the gathering and presentation of facts. More importantly, most of their advice communicating law to clients, and helping clients structure transactions to conform to law, and negotiating with others in the shadow of the law, will never be reviewed by any authoritative interpreter. The practicing lawyer's - perfectly sincere - working idea is that conformity with any plausibly arguable construction of legal texts and precedents as applied to what the client wants to do, even those that thoroughly frustrate the law's purpose, is "perfectly legal," so that the state would violate "the Rule of Law" by sanctioning it. "Creative compliance" thus becomes a tactic of using rule-formality against itself, so as to nullify the force of rules. ${ }^{24}$ Again, this kind of interpretive anarchy can be moderated, and sometimes is, by strongly internalized guild conventions stabilizing and standardizing approved readings of legal texts. But in many kinds of practice, perhaps especially these days regulatory and tax practice, the professional norms tilt towards anarchy, as "whatever helps the client." The most flattering account of this practice is that it sets in motion an iterative game, in which lawyers probe the weak spots and help identify overreaching or counterproductive elements of regulation, prompting smarter and more fine-tuned regulatory responses. The darker view is that it sabotages the state's capacity to tax and regulate well-lawyered parties; and that in societies where state administrative capacity is weak to begin with, it makes governance impossible. It now appears that the use of legalism to work around regulatory safeguards that are supposed to protect companies and their stockholders, investors and the public from fraud and excessive risk-taking is one of the causes of the current collapse of the world economy.

If legalism sometimes helps to produce anarchy instead of containing it, what of the claim that law displaces violence? As Robert Cover memorably pointed out, law is a form of violence - maybe contained and legitimated violence, but violence nonetheless, and often the more brutal for having been legitimated. ${ }^{25}$ In a brilliant and terrifying essay, John and Jean Comaroff note the "new fetishism" for law in postcolonial societies, among regimes

24 For many examples taken from lawyers' gaming of UK company and tax law rules, see Doreen McBarnet \& Christopher Whelan, The Elusive Spirit of the Law: Formalism and the Struggle for Legal Control, 54 MoD. L. REv. 848 (1991).

25 Robert Cover, Violence and the Word, 95 YALE L.J. 1601 (1986). 
like Robert Mugabe's in Zimbabwe that use law to punish opponents, among private entities that use it for predation, among weaker parties who seek to turn it on itself. The "culture of legality" means that everyone tries to appropriate law's legitimating magic, including criminal gangs, who produce "simulacra" of legality, just as states, in Charles Tilly's account, once took over the functions of protection in return for pay of criminal gangs. ${ }^{26} \mathrm{Law}$ has indeed become a universal language, but hardly one of regularity and order.

\section{On Political Liberalization}

Many, perhaps most, of the world's legal professions since early modern times have made large claims about how their work and their ideals serve the cause of political freedom.

The humanist lawyers of early modern Europe adopted as their patron the (considerably glamorized) example of Cicero: the lawyer who deploys eloquence and learning in the defense of republican liberty. Leading American lawyers of the nineteenth century embraced something like this humanist republican view of their vocation, claiming it to be a disinterested profession, independent both of governments and particular factions of civil society, able to mediate between populism and plutocracy in the service of the common good.

In modern times, it has been claimed that the organization of the bar in autonomous self-regulating associations is the essential condition of

Lawfare can be limited or it can reduce people to "bare life" - in Zimbabwe, it has mutated into a deadly necropolitics with a rising body count . . . but it always seeks to launder brute power in a wash of legitimacy, ethics, propriety. Sometimes it is put to work, as it was in many colonial contexts, to make new sorts of human subjects; some-times it is the vehicle by which oligarchies seize the sinews of state to further their econo-mic ends; sometimes it is a weapon of the weak, turning authority back on itself by commissioning the sanction of the court to make claims for resources, recognition, voice, integrity, sovereignty. But by and large, as we have said, it is neither the weak nor the meek nor the marginal who predominate in such things. It is those equipped to play most potently inside the dialectic of law and disorder. . . . The court has become a utopic institutional site to which human agency may turn for a medium in which to achieve its ends - albeit sometimes in vain, given the disproportion everywhere between populist expectations of legal remedy and, law-oriented nongovernmental organizations notwithstanding, access to its means.

John L. Comaroff \& Jean Comaroff, Introduction to LAW AND DISORDER IN THE POSTCOLONY 1, 31-33 (John L. Comaroff \& Jean Comaroff eds., 2006). 
freedom. As Rudolf von Gneist, one of the architects of the German profession of advocates, rather grandly put it in 1867, "The free practicing bar means nothing less than the precondition for all independence of communal life, of self-government, of constitutional life on the largest scale."27 Or more prosaically, as in the slogan plastered on the walls of a recent annual ABA meeting: "Liberty - Justice - Rights. Without Lawyers These Are Just Words." The French bar interpreted autonomy to require independence from both the state and commercial interests, and even from other lawyers. ${ }^{28}$

At the same time, professions of advocates have often tended to favor a libertarian ideology. Their function is to protect individual liberty and property against an overreaching state. The inspiring examples come from political trials of dissenters and pariahs: in the Anglo-American tradition, Thomas Erskine's defense of Tom Paine, or John Adams's defense of the Boston Massacre soldiers who fired on a crowd of protesting colonists.

The realities are generally more humdrum. There can surely be no profession where the gulf is wider between soaring aspirations and habitual practices. The renaissance humanist lawyers were certainly civically virtuous in that they sought service in public office (in part as a means to attract clients); but the public good was always the good of the city-state, and the law that which the state enacted in its statutes; and the state was the prince or the oligarchy. ${ }^{29}$ Evidently the professional agenda is not by any means inherently anti-statist. In most societies lawyers work for the state, or under strong state supervision; their fortunes and careers are tied to the state; and they are very conservative, in the literal sense. Even Latin American lawyers, who have always thought of themselves as an independent liberal profession, in fact overwhelmingly work for the state. ${ }^{30}$ Furthermore, prevailing jurisprudence, even much of Western origin, is hardly necessarily one of liberal norms. Positivists tend to follow rules laid down by authorities; natural-law-oriented or purposive lawyers may have an orientation toward Order, or the Nation, or the Public Good that is just as or more submissive to authority. The peculiarly German forms of legal liberalism - the ideals of liberality realized through lawyers university-trained in norms of a system of private law that guaranteed individual liberalism - had literally nothing to say to lawyers about the

27 Rudolf von Gneist, Die Freie Advocatur. Die erste Forderung aller JUSTIZREFORM IN PREUSSEN 49 (Berlin, J. Springer 1867).

28 JOHN LEUBSDORF, MAN IN His ORIGINAL Dignity: LEGal ETHICS IN FranCE (2001).

29 See Lauro Martines, Lawyers and StateCraft in Renaissance Florence $387-448$ (1968).

30 Rogelio PÉrez-PERdomo, LATIN AMERICAN LAWyers: A Historical INTRODUCTION 90 (2006). 
legitimate sphere of public law, state guarantees of order. Public law was a separate science, founded on reason-of-state, not liberal ideals. ${ }^{31}$ In most of the modern world until recent times, the Western Rule of Law was an imposition on colonial peoples of imperial rule, with lawyers sent out from the metropole, and lawyers recruited from the colony into imperial service, as its agents. Or it was the recognizable ancestor of today's neo-liberal Rule of Law, a body of rules imposed by rich nations on poor ones, protecting rich countries' investors against expropriation, or their contracts against revision, by such forces as nationalist revolutions; and enforced by Marines or foreign-organized and subsidized countercoups.

As for the professional ideals of independence and autonomy, which the Rule of Law projects look to lawyers to promote, they have indeed contributed something to liberal political movements, as I'll explain in a moment, but their main deployment has been in the service of protecting professional privileges, fees and cherished customs. English barristers, who turned out some of the most extravagant rhetoric celebrating their role as guardians of the constitution, the Rule of Law, and English liberty, by 1800 had settled into a cozy, insular, incurious parochialism, carefully cultivating the technical learning of Westminster Hall and the "etiquette" and traditions of the Inns of Court and circuit messes. They had, David Lemmings says, the great self-esteem that comes from belonging to a social elite: the ideal barrister was snobbish rather than virtuous! He did have a public mission, what Lemmings calls maintaining "the essentially negative political trust. As a fully paid-up member of the new conservative elite of the propertied and politely educated, he would defend the status quo against the influence of modern liberal heresies." 32 The English profession was not under the thumb of the state - although promotion to high court judgeships, the most coveted crown of a career, was heavily dependent on government patronage - but it was a conservative closed club, very unfriendly to lawyers who represented radicals or other outsiders too aggressively. ${ }^{33}$

In the United States the ideal of the disinterested republican lawyer, standing above governments and factions to promote the common good,

31 Hannes Siegrist, AdVocat, Bürger und StaAt (1996); KenNeth F. LedFord, From GENERAL ESTATE TO SPECIAL INTEREST (1996).

32 David Lemmings, Professors of the Law: Barristers and English Legal Culture In THE EighteEnTH CENTURy 312 (2000).

33 See W. Wesley Pue, Exorcising Professional Demons: Charles Rann Kennedy and the Transition to the Modern Bar, 5 LAW \& HIST. REV. 135 (1987); W. Wesley Pue, Rebels at the Bar: English Barristers and the County Courts in the 1850s, 16 ANGLO-Am. L. REV. 303 (1987). 
was always in tension with the ideal of the partisan advocate fighting fiercely for his clients; ${ }^{34}$ it was put under serious strain by the demands of business clients for exclusive loyalty; and finally vanished even as a purely expressive aspiration from the rhetoric of the elite corporate bar in the 1970s. Elite lawyers were independent of the state in the peculiar sense that they were not controlled by it: indeed they tended to control the state, as legislators and officials temporarily on leave from private practice. But increasingly they sacrificed what they had of independence from clienteles, and became a commercial service profession, who happily shunted off their civic-republican functions (except for a small saving remnant of pro bono work) to government lawyers, academics, and a small low-paid corps of specialized "public interest" lawyers. ${ }^{35}$

The more explicitly libertarian advocacy ideal has had a similarly shaky history. In the United States - where, to be fair, it has been more vigorously lived out in some lawyers' practices than almost anywhere else - the elite bar has appropriated it mainly to explain its defense of sometimes unpopular corporate interests from state regulation. Until very recent times, elite lawyers (with a few exceptions like the antislavery lawyers) left the defense of pariahs, dissenters, and subordinate groups to lawyers at the fringes of the profession - Jews, Communists, blacks, women. It has only been after those activists succeeded in promoting a rights revolution, supported by the highest precincts of the judiciary, that the respectable bar embraced their causes. ${ }^{36}$ In South Africa, similarly, only a few brave lawyers took up the cause of antiapartheid liberalism; most of the bar was inert or hostile. ${ }^{37}$

Political liberalization is nonetheless the field in which lawyers and legal professions have achieved their most notable successes. English lawyers, as is well known, stood for the Rule of Law, parliamentary liberties and independent courts in the English Revolutions of the seventeenth century. American colonial lawyers argued the case for independence and afterwards did the major work of constitution-making and building and staffing legal institutions in the new nation. French lawyers fought for

34 See Norman Spaulding, The Myth of Civic Republicanism: Interrogating the Ideology of Antebellum Legal Ethics, 71 FORDHAM L. REV. 1397 (2003).

35 See Robert W. Gordon, The Independence of Lawyers, 68 B.U. L. REV. 1 (1988).

36 See Jerrold Auerbach, Unequal Justice: LaWyers and Social Change IN MODERN AMERICA (1976).

37 See David Dyzenhaus, Judging the Judges, Judging Ourselves: Truth, ReCONCILIATION AND THE Apartheid Legal ORDER (2003); Richard L. ABEL, POLITICS BY OTHER MEANS: LAW IN THE STRUGGLE AGAINST APARTHEID, 1980-1994 (1995). 
political liberties before the Revolution and (after an interval of succumbing to the Revolution's extinguishing of all opposition) the nineteenth-century freedoms of speech, the press and assembly: they used defense of the accused in political trials instigated by authoritarian regimes to agitate for republican liberties, and moved into major parliamentary and executive posts in republican governments. ${ }^{38}$ It was usually colonial lawyers, like Gandhi, Jomo Kenyatta, and Nelson Mandela among innumerable others, who took the lead in resistance movements to imperial rule; and often lawyers and bar associations who mobilized in the struggle for basic legal freedoms against authoritarian regimes such as those of South Korea, Taiwan, Malaysia, Egypt, Spain, South Africa, Chile, and Brazil. ${ }^{39}$ Sometimes lawyers did this in the course of their ordinary work of representing clients, converting (in the Ciceronian mode) ordinary criminal or civil libel trials into dramatic political test cases. More often lawyers mobilized politically, forming an autonomous interest group like the Pakistani lawyers who led street protests in their dark suits and ties against Pervez Musharraf's firing of the Chief Justice and his successor's refusal to reinstate him. Sir Edward Coke is known as the Chief Justice who stood up to King James; but in fact his most effective political work was in his later career as a member of Parliament, in defense of the liberties of Parliament. ${ }^{40}$ Liberal Prussian judges organized politically to protect their independence by standing for, and forming an opposition bloc within, the nineteenth-century Prussian Parliament. ${ }^{41}$ Bar associations - not generally the most courageous or liberal-minded of institutions - have been most likely to join in resistance to authoritarian rule where they had some traditions of autonomy they were motivated to defend.

More indirectly, an autonomous profession can be an agent of political liberalism simply by virtue of its existence as an independent power center whose norms and orientation are different from the state's, so that it

38 LUCIEN KARPIK, FRENCH LAWYERS 116-39 (1999).

39 On these movements, see especially the excellent case-studies collected in LAWYERS AND THE RISE OF WESTERN POLITICAL LIBERALISM (Terence C. Halliday \& Lucien Karpik eds., 1997), and in Fighting for Political Freedom: Comparative Studies of the Legal COMPleX AND POlitiCal Liberalism, supra note 14. For counterexamples, featuring judges and lawyers acting as agents of repressive regimes, see RULE By LAW: THE POLITICS OF COURTS IN AUTHORITARIAN REgIMES (Tom Ginsburg \& Tamir Moustafa eds., 2008).

40 Stephen D. White, Sir Edward Coke and "The Grievances of the COMMONWEALTH" (1979).

41 Kenneth F. Ledford, Judicial Independence and Political Representation: Prussian Judges as Parliamentary Deputies, 1849-1913, 25 LAW \& Soc. INQUIRY 1049 (2000). 
can provide some cover or protection from state persecution, or more affirmatively, a place of resistance to state authority. To put this another way, the culture of legalism may help to promote political pluralism because it can multiply procedures, rule-following temperaments, and entrenched professional practices that are askew to or somewhat resistant to outside control and manipulation. In Germany, for example, nineteenth-century private-law science favored a liberalizing agenda in some respects, an evolution away from the neo-feudal estates system in the East. ${ }^{42}$ Lawyers arguing for limited reforms, on behalf of restricted clienteles, develop general languages of rights that become available to new groups fighting for a place in the sun, which put them to uses never anticipated or desired by their inventors. Also such associations and their personnel are most likely to be penetrated by foreign intellectual influences and contacts with foreign notables, which may be additional sources of prestige and authority. An autonomous independent profession may be more likely to produce mavericks or social cranks or rightsentrepreneurs, people who actually take seriously and live out the professed liberal ideals of the profession that most lawyers ignore in practice; as well as to spark the proliferation of professional institutions such as law schools, legal research institutes, code commissions, etc. with reformist agendas.

These are inspiring examples, and to the limited extent that actual historical experience, as contrasted with pure theory or mythmaking, has informed the Rule of Law export projects, these liberal lawyers' movements may be responsible. (Ibrahim Shihata, the chief theorist of the World Bank's Rule of Law projects, is an Egyptian presumably familiar with Egyptian lawyers' centrality to liberal reform movements in the 1920 s and ' 30 s and then again post-1970.43) But they have led to some wildly overoptimistic hopes that lawyers and their associations will act as an interest group with a built-in liberal tilt. ${ }^{44} \mathrm{~A}$ lawyer or legal profession's record as promoter or defender of political liberalization tells you little or nothing about where he or

42 James Whitman, The Legacy of Roman Law in the German Romantic ERa (1988).

43 Farhat J. Ziadeh, Lawyers, The Rule of Law and Liberalism in Modern EGYPT (1968); Tamir Moustafa, Mobilizing the Law in an Authoritarian State: The Legal Complex in Contemporary Egypt, in Fighting FOR POLITICAL FrEEDOM: COMPARATIVE STUdies OF THE LEGAL COMPLEX AND POLITICAL LibERALISM, supra note 14 , at 193 .

44 Such hopes are particularly visible in projects to promote the rule of law in China. For some measured skepticism about these projects, see William P. Alford, of Lawyers Lost and Found: Searching for Legal Professionalism in the People's Republic of China, in RAISING THE BAR: THE EMERGING LEgal PROFESSION IN EAST ASIA 287 (William P. Alford ed., 2007). 
they will stand on broader liberal measures or movements, such as those for social liberalism or inclusive democracy. ${ }^{45}$ Formal equality of persons before the law is hardly the same thing as equality of access to resources or equality in distribution of social goods; and the two ideals may and often do conflict in practice (vide recent bitter quarrels over affirmative action and universal health care). Lawyers and their associations have as often as not been a politically conservative force, one that resists extension of suffrage, more inclusive political participation, and designs to implement social and economic rights to security and equality. French lawyers, for example, who of all Western legal professions were the most consistent and cohesive in their defense of political liberties in the nineteenth century, sided with the forces of established power, order, and social respectability in the Dreyfus affair; and solidly set themselves against working-class claims for social security and a larger share of economic power. ${ }^{46}$ Legalism can be markedly antidemocratic — promoting the Rule of Law through courts in order to locate decision-making out of the reach of the swinish multitude. Elite lawyers have been very supportive of authoritarian suppression of labor, political dissenters, strangers and outsiders. Lawyers in general have the most social sympathy with those who can pay their bills, and little time and patience for anyone else. ${ }^{47}$ Constructing a very conservative version of public order is a goal that often trumps norms of due process and actually presupposes unequal treatment of some groups, like women or labor or ethnic minorities, as naturally subordinate. And - once again - many legal professions are uncritical servants of the states that support their privileges and supply directly or indirectly their means of livelihood.

\section{ON ECONOMIC LibERALIZATION}

There are, of course, plenty of theories of the essential role of law in producing and securing the essential framework of capitalist markets - property rights, contract enforcement, specific forms of corporate

45 This is the general conclusion of the editors of an extensive series of case-studies of the relations of lawyers to movements for political liberalism. Terence Halliday, Lucien Karpik \& Malcolm M. Feeley, The Legal Complex in Struggles for Political Liberalism, in Fighting FOR POlITICAL FREEDOM: COMPARATIVE STUdies OF THE LEGAL COMPLEX AND POLITICAL LIBERALISM, supra note 14, at 1.

46 KARPIK, supra note 38, at 138-39.

47 For examples of such unsympathetic lawyers, even in a society with strong public norms of social solidarity and equality, see Ethan Michelson, The Practice of Law as an Obstacle to Justice: Chinese Lawyers at Work, 40 LAW \& SOC'Y REV. 1 (2006). 
organization, and the like; and even (from the "origins" school of legal economics) some theories about which legal traditions are best suited to produce them (in this case common law rather than civil law). As we've seen, in the Rule of Law export projects the agents picked out to staff these legal institutions are mainly judges, with a supporting cast of lawyers and other functionaries added as an afterthought. ${ }^{48}$

The most prominent theory of lawyers' roles in promoting liberal capitalism by building the institutions of the Rule of Law is, of course, Max Weber's. The theory is convoluted and, as many generations of interpreters have commented, rather opaque. Weber seems to propose an instrumental story, then partially retracts it and replaces it with a cultural story. ${ }^{49}$ By separating law from religion and tradition and freeing it from direct political intervention, legal professions built logically-formally rational legal orders based on general principles (or somewhat less formally rational common-law systems based on precedents), thus creating a predictable environment for private property-holding and commercial transacting. The

48 See, for example, Richard Posner on the ideal form of a legal system:

[T] $]$ he machinery consists of competent, ethical, and well-paid professional judges who administer rules that are well designed for the promotion of commercial activity. The judges are insulated from interference by the legislative and executive branches of government. They are advised by competent, ethical, and well-paid lawyers. Their decrees are dependably enforced by sheriffs, bailiffs, police, or other functionaries ... . The judges are numerous enough to decide cases without interminable delay, and they operate against a background of rules and practices, such as accounting standards, bureaus of vital statistics, and public registries of land titles and security interests, that enable them to resolve factual issues relating to legal disputes with reasonable accuracy and at reasonable cost to the disputants.

Richard A. Posner, Creating a Legal Framework for Economic Development, 13 WORLD BANK RES. OBSERVER 1, 1-2 (1998), available at http://siteresources.world bank.org/INTLAWJUSTINST/Resources/LegalFramework.pdf.

49 The clues to Weber's view of the role of lawyers in producing the conditions under which capitalism appeared in, and only in, the West are scattered throughout his work; see especially 2 MAX WEBER, ECONOMY AND SOCIETY 784-808 (Guenther Roth \& Claus Wittich eds., 1968) ("The Legal Honoratiores and the Types of Legal Thought"); Id. at 973-79 ("The Technical Superiority of Bureaucratic Organization over Administration by Notables"). Exceptionally helpful modern guides to Weber's thinking about law, lawyers and capitalism are David Trubek, Max Weber on Law and the Rise of Capitalism, 3 WIS. L. REv. 720 (1972), and Duncan Kennedy, The Disenchantment of Logically Formal Legal Rationality: Or, Max Weber's Sociology in the Genealogy of the Contemporary Mode of Western Legal Thought, in MAX WEBER'S ECONOMY AND SOCIETY, A CRITICAL COMPANION 322 (Charles Camic, Philip S. Gorski \& David M. Trubek eds., 2005). 
lawyers' intellectual project and their guild's self-promotional honor-andstatus-seeking strategy supplied the material to enable and make operationally possible a set of political bargains: Both rulers and merchants wanted more predictable rule-systems, the rulers to extend the reach and efficiency of rule, the merchants to limit the rulers' power by regularizing its uses. And the resulting regimes of legal autonomy - differentiated rule-systems, administered by differentiated professionals - thus created the conditions for capitalist development. Interestingly, though, the perfected professional experts in Weber's story turn out to be not private lawyers (the Anwaltschaft), but the bureaucracy (the Beamtenstand), legally trained functionaries capable of "objective" administration, "according to calculable rules and "without regard for persons'" 50 - in short the rule of law and not of men. Weber then considerably clutters up his own account by honestly admitting that logically formal rules actually aren't always that predictable and in practice frustrate the expectations of businessmen, and for that reason are being supplanted by specialized, substantively rational bodies of law and administrators. ${ }^{51}$ Ultimately, it seems that the lawyers' accomplishment was more than anything the construction of the culture of secular rationality, the idea of a science autonomous from religion, custom and tradition and from particular estates and orders, and a universal science capable of totally dominating other normative orders as a mode of governance, and by so doing "disenchanting" the magical pre-modern world.

The current Rule of Law projects tend to vulgarize Weber's very complicated historical story into the simple proposition that Western legal systems were a functional response to capitalists' needs for predictability; and that if lawyers are independent of state domination and work for commercial clients, they will bring about conditions generally favorable to capitalism. Over time I've become used to seeing legal historians'

50 See WeBER, supra note 49, at 975.

51 See the sensible observations of Lawrence Friedman:

Weber (at least in his instrumental mode) tended to exaggerate the importance of systematic legal thought. Granted, a legal system needs to provide a minimum of order and predictability .... What is less obvious is whether any particular kind of order and predictability, beyond these minima, is essential. Perhaps an honest court system, a stable society and strong institutions are enough ... [S]ociety tolerates legal formalism only where it does not matter very much. Elsewhere, it is substantive rationality that rules. The actual work of the lawyers . . . is strongly pragmatic, substantive, directed toward concrete results.

Lawrence M. Friedman, Lawyers in Cross-Cultural Perspective, in LAWYERS IN Society, Volume 3: Comparative Theories 1, 17-19 (Richard A. Abel \& Philip S.C. Lewis eds., 1989). 
jaws drop when they hear legal economists asserting that lawyers especially common lawyers - produced efficient rule systems in response to commercial needs. The English common law, Lawrence Friedman remarks mordantly, "may have done its bit for commercial development by ignoring commercial law, while protecting it from interference by the common lawyers. "52 At the start of the Industrial Revolution, the English bench and bar, with the rare exception like Lord Mansfield, made no attempt to accommodate law to urban business interests who found the legal system full of "not only high fees but wrong answers." ${ }^{53}$ Ron Harris has convincingly shown that English lawyers and judges in the same period were unable to do much to develop the unincorporated enterprise forms that business ventures needed to compensate for their inability to obtain corporate charters. He concludes that

[their] moderate achievements were subject to the need to apply many complicated and limiting devices, to follow lengthy procedures, to negotiate and draft documents involving high legal costs, and to arrive at a legal outcome which was less than satisfactory, because many legal doubts and practical uncertainties remained. ... [An] outcome . . . less than satisfactory in terms of overall social costs, efficient allocation of resources, and eventually the rate of growth of the English economy. ${ }^{54}$

Things did not improve when the common-law judges determined to bring major industrial enterprises into their jurisdiction. At the height of the boom for railway construction, English lawyers tormented their railway clients by devising incredibly complex procedures that required high fees to negotiate. Rande Kostal shows how lawyers set up elaborate, formal, trial-type hearings in Parliamentary anterooms to adjudicate requests for charters, and similar proceedings to get rights of way. After about twenty years of paying enormous fees for this kind of service, the railway clients finally wised up, got the statutes changed to simplify and generalize procedures, and hired house counsel to routinize transactions. ${ }^{55}$ Railway interests concluded that

the fundamental problem . . . was that English railways had been too

52 Id. at 17.

53 LEMMINGS, supra note 32, at 91.

54 RON HARRIS, INDUSTRIALIZING ENGLISH LAW: ENTREPRENEURSHIP AND BUSINESS ORGANIZATION, 1720-1844, at 167 (2000). Harris does suggest, however, that the English legal system was somewhat more functionally adapted to the development of English capitalism in the periods before and after the late-eighteenth to midnineteenth centuries.

55 R.W. Kostal, Law and English RaIlway Capitalism, 1825-1875, at 110-43 (1994). 
little governed by deliberate and facilitative policies of the central state, and too much by the antiquated ideas and institutions of the common law. ... After decades of de facto regulation by lawyers and judges, railway executives were beginning to consider the virtues of a Prussian-style alliance between private corporations and the central state..$^{56}$

Max Weber may have been on to something after all.

Even as faithful agents of business clients, lawyers often seriously disserve both the workings of capitalism and the Rule of Law. Their interest, after all, is in securing good deals and favorable treatment for clients subsidies, exemptions, concessions, licenses, franchises, or protection from competition - not the overall efficiency of the economy. To this end, lawyers do sometimes invest efforts in producing a more globally rational system. In the United States, one finds lawyers leading the movements to build the institutions of constitutional government and a national common market in the Federal period; to replace corrupt judges and replace patronage administration with a professional civil service in the late nineteenth century; to build the major institutions of the administrative state in the twentieth; and, more prosaically, to construct an expanded, more efficient, fair, affordable and workable regime of bankruptcy administration in $1978 .{ }^{57}$ But corporations don't always prefer the Rule of Law; sometimes they are just as happy with a regime of corrupt ad hoc deals, ${ }^{58}$ and in such situations they may find it useful for their agents, often lawyers, to play the role of fixer, master of informal methods of getting clients favorable deals with the state. ${ }^{59}$ This helps some enterprises, but not necessarily capitalism generally;

56 Id. at 371-72.

57 For these examples, see Terence C. Halliday \& Bruce G. Carruthers, Making the Courts Safe for the Powerful: The Commercial Stimulus for Judicial Autonomy in Reforms of the United States' Bankruptcy Law, in LAWYERS AND THE RISE OF Western Political Liberalism, supra note 39, at 265; David A. Skeel, JR., DEBT'S DOMINION 131-59 (2001).

58 See Susan Rose-Ackerman, "Grand" Corruption and the Ethics of Global Business, 26 J. BANKING \& FIN. 1889 (2002).

59 See Jane Kaufman Winn, The Role of Lawyers in Taiwan's Emerging Democracy, in RAISING THE BAR: THE EMERGING Legal PROFESSION IN EAST ASIA, supra note 44 , at 357, 375-78, for an interesting analysis of Taiwanese lawyers' participation in the formal legal and informal "fixer" zones of practice.

Ronen Shamir tells us that American business lawyers in the New Deal, although on principle upholders of the constitutionalized classical private-law framework for a free market of lightly regulated producers, swallowed their reservations and supported the most radical anti-classical New Deal experiment, the corporatist 
and it obviously undermines Rule of Law ideals and in the not-so-long run encourages generalized corruption. So, too, when lawyers help established businesses entrench themselves against newcomers, or so overreach that they invite countermeasures inspired by middle-class moral revulsion or populist rebellion. In very recent times we have seen lawyers, purporting only to zealously represent business client interests, help the managers loot the clients for their own benefit and bring the clients crashing down, and along with them a substantial portion of the world economy.

\section{SOME OBSERVATIONS IN CONCLUSION}

I'm very much afraid that this has been another typical historian's intervention in a policy debate: "It's just all so terribly complicated and it doesn't clearly point to any definite or reliable set of conclusions." Perhaps, however, we can pull out of this story a few slightly more concrete general observations that policy planners and activists might possibly find of some use.

One is simply to reinforce an observation that critics of the Rule of Law projects have frequently made: the Rule of Law is not a technology, a module of specific legal practices that can simply be implanted in a society and expected to start working as advertised, grinding out predictable enforcement of legal rules which in turn generates compliance with those rules. Legal systems that are relatively impartial and capable of efficiently enforcing their judgments are exceedingly rare in the world - accessible and affordable ones even more so; and where they do exist, they are the product of historical contingencies and a world of supplementary non-legal civil-society associations and institutions that are hard to directly engineer. If one hopes to produce such a system, it's probably best to start with examining the potential political and social foundations for it: the bargains that political elites and major interest groups may find it advantageous to strike to transfer authority to institutions not under their direct control or influence; the protections that judges receive against bribery and intimidation; the supplementary associations, local tribunals, and informal private-ordering

National Industrial Recovery Act, because their clients did; and only turned against it when their clients did as well. See RONEN SHAMIR, MANAGING LEGAL UnCERTAINTY: ELITE LAWYERS IN THE NEW DEAL (1995). 
enforcement mechanisms by means of which most conflicts have to be settled so that only problem cases are brought to court.

Far too much is expected of judges and lawyers in the Rule of Law projects: far more, certainly, than historical experience would suggest they are capable of delivering. Judges have to depend largely on lawyers to bring clients and claims to courts; yet lawyers, if only to make a living, tend to filter out most claims and clients and thus effectively defeat the ideal of equality before the law. Lawyers are to be independent, yet loyal to clients; strenuous advocates for client's positions, yet also supportive of aims of some degree of social solidarity; bearers of universal cosmopolitan norms, but builders of nations and national cultures; resistors of predatory states, but not subverters of legitimate state authority; governors of self-regulating autonomous professional bodies, but not unduly self-interested. Many of the models of law practice that the West is exporting to the rest of the world - such as, for example, Americans' unbelievably cumbersome and expensive litigation practices, or aggressive regulatory arbitrage and "creative compliance" — would seem utterly destructive of developing societies' capacities to regulate and tax to supply public goods. (On the other hand, the export of public-interest advocacy seems on the whole to be a significant force for good.)

Many of the Rule of Law projects assume that courts staffed by independent legal professionals are preferable to bureaucratic government. This is partly because of (what I and many others think is) a profoundly mistaken view that states in developing and transitional societies are too strong, whereas the larger problem is that they are too weak to resist corruption, capture, or determined sabotage by powerful interests. But the assumption also seems to owe something to the amazingly durable Dicey-Hayek-derived romantic view of the ideal state as a common-law state, in which all controversies between private parties, and between private parties and the state, are brought to law courts for resolution according to common-law rules or something like them. Yet in the Western societies that came closest to the model of the common-law state, Britain and the United States, few other than the lawyers themselves have ever perceived the unique virtues of the courts and common law as instruments of governance. Both private groups and officials did their best to work around them by creating a host of alternative institutions: administrative agencies, specialized tribunals, local lay magistrates, and non-judicial enforcement mechanisms like arbitration. It may very well be that instead of pursuing fantasies of governance by courts, many societies would do better to focus on trying to develop corps of honest and competent officials to administer routine procedures. 
At the same time as it tends to romanticize legal professions as agents of the Rule of Law, the view of law as technology and of lawyers and judges as its technicians also tends to overlook some of lawyers' most valuable contributions to the building of liberal societies, which take the form of political and cultural expression. I've mentioned the often crucial political roles of lawyers mobilized to lead liberal revolutions and nation-building, colonial revolts, and opposition to oppressive regimes. Even more important in the long term has been the role of lawyers as builders of modern culture. I have mentioned Weber's theory of lawyers as the crucial architects of rational-formal legality, separated from religion and custom, as the archetypical mode of public reasoning and as what legitimates domination. The Renaissance historian William Bouwsma has a different view of the cultural mentality diffused by lawyers in earlymodern Europe: pragmatic, empirical, distrustful of grand systems and absolutes, concerned with the workable, aware that rules and institutions are transitory and mutable, and must be adjusted to changing times. ${ }^{60}$ Bouwsma sees lawyers as foxes, Weber sees them as hedgehogs; but they both see lawyers as "disenchanters," pioneers of secular culture. Lawyers, as Donald Kelley and John Pocock have shown, were among the creators of modern historical method and the consciousness that societies exist in time and are subject to progress and decay; they used history to show where law had come from, revealing origins to trace the genealogy of modern doctrines, exploding founding myths while providing both a rationale for dynamic adaptation of law to changing circumstances and the reassurance of an anchor in traditions. ${ }^{61}$ Lawyers supplied the ideological rationales for the great "bourgeois" revolutions of England, France and America by converting the specialized, technical, languages of law into a general discourse of liberty

60 William J. Bouwsma, Lawyers and Early Modern Culture, 78 AM. HIST. Rev. 303, 314 (1973). James A. Brundage's magisterial Medieval Origins of the Legal Profession similarly points to lawyers as agents of intellectual pluralism and innovation because they

were less hemmed in than theologians were by dogmatic boundaries. . . . Canonists explored and developed novel ideas about such basic issues as natural rights, representation and consent, the corporate structure of ecclesiastical and civil government, the right to wage war, or limits on the authority of popes, bishops and cardinals, or even monarchs, more freely than their colleagues in the theological faculty ....

James A. Brundage, Medieval Origins of the Legal Profession: Canonists, CiVILIANS AND COURTS 467 (2008).

61 See, e.g., Donald Kelley, Foundations of MOdERn HistoriCal Scholarship (1970); J.G.A. POCOCK, THE ANCIENT CONSTITUTION AND THE FEudAL LAW (1957). 
and rights. The common law, for example, was turned from a collection of writs and specialized sciences of pleading and property interests into a repository of public law maxims and fundamental law, the constitutional rights of freeborn Englishmen, and eventually of all men everywhere. ${ }^{62}$ I've tried in previous work to argue that lawyers are architects of ideological frameworks meant to bridge the gap between the actual and the ideal, to fit the quotidian interests and activities of clients, and the regulatory activities of states, into larger systems of order that give them meaning, order, and consonance with normative values and traditions. ${ }^{63}$ In his pioneering study of English, Jewish and Arab lawyers in Mandate Palestine, Assaf Likhovski has made a strong case for seeing law as a means of representing, reflecting, and thus helping to create national, religious, ethnic or cultural identity, the self-image of a society or legal system - Western, non-Western, alternative Western, customary, traditional, modern, or mediating among all these. Lawyers' work is often best understood not simply as instrumental to some set of client interests, or guild interests, or even to "change social reality," but to protect and promote images of identity. ${ }^{64}$ One would not expect program officers for the World Bank or USAID to focus very closely on the cultural and ideological roles of lawyers; but if one is looking for potential sources of long-term social influence, that may be the best place to look.

I will conclude with the reflections of a great Anglo-Israeli legal scholar about the Rule of Law:

It is to be insisted that law is only one of the values that a legal system may possess and by which it is to be judged. It is not to be confused with democracy, justice, equality (before the law or otherwise), human rights of any kind or respect for persons or the dignity of man. A non-democratic legal system, based on the denial of human rights, on extensive poverty or racial segregation, sexual inequalities and

62 See, e.g., Richard Ross, The Commoning of the Common Law: The Renaissance Debate Over Printing English Law, 1520-1640, 146 U. PA. L. Rev. 323 (1998); DANIEL J. HULSEBOSCH, CONSTITUTING EMPIRE (2005). Ironically, soon after lawyers helped convert law into a popular language of rights and self-government, the professional elite undertook to change it back again into a specialized science accessible only to the deeply and broadly educated.

63 See, e.g., Robert W. Gordon, The Ideal and the Actual in the Law: Fantasies and Practices of New York City Lawyers, 1880-1910, in ThE New High PRIESTS: LAWYERS IN POST-CIVIL WAR AMERICA 51 (Gerard W. Gawalt ed., 1984).

64 Assaf Likhovski, Law and IDENTITY in Mandate Palestine (2006). For a collection of essays on similar themes, see LAWYERS AND VAMPIRES: CULTURAL Histories of LeGAL Professions (W. Wesley Pue \& David Sugarman eds., 2003). 
religious persecution may, in principle, conform to the requirements of the rule of law better than any of the legal systems of the more enlightened Western democracies. This does not mean that it will be better than those Western democracies. It will be an immeasurably worse legal system, but it will excel in one respect: in its conformity to the rule of law. ${ }^{65}$

That is Joseph Raz, on the "Rule of Law and Its Virtues." If the Rule of Law is given the relatively formal definition that Raz gives it, we may well pause to wonder whether these are really the virtues to which global development policy should give such pride of place. The Rule of Law virtues are those that enable people to predict the conditions under which the state will sanction them and to plan their affairs accordingly. The rules may be just or unjust, kind or cruel in their operation, enabling to the rich and constraining to the poor. Their operation is hardly an absolute or unqualified good; it may in practice lead to many horrible results; it may foreclose movements to superior institutions; it may lend barbaric rulers a patina of legitimacy. But in some societies, especially those emerging from anarchy and endless cycles of ethnic conflict, it may be provisionally superior to available alternatives. There is undeniable appeal to the idea of a sphere of decision-making that is (relatively) regular, stable, predictable, and above all not subject to ad hoc intervention by powerful officials or interest groups. As we've seen, though, it's far from clear that lawyers are effective builders of even the minimal version of Rule of Law: they are sometimes, out of self-interest or even by vocation, its saboteurs. In any case, as Raz says, the Rule of Law is not to be confused with nor is it an adequate substitute for other social goods; and if it is conflated with those other goods, as has happened in most of the Rule of Law export projects, there may be other and more direct ways of pursuing those goods than by trying to replicate the judges and lawyers, the courts and bar associations and law schools, the methods and mentalities of the Western European and North American experience, in forms often so idealized as to be almost imaginary.

65 JOSEPH RAZ, The Rule of Law and Its Virtues, in THE AUTHORITY OF LAW 210, 211 (1979). 